\title{
Reakcja pszenicy zwyczajnej ozimej na dolistne nawożenie
}

\author{
The reaction of winter wheat to foliar fertilization
}

\author{
Wacław Jarecki $₫$
}

Zakład Produkcji Roślinnej, Uniwersytet Rzeszowski, 35-601 Rzeszów, ul. Zelwerowicza 4

$\triangle$ e-mail: jarecki@ur.edu.pl

\begin{abstract}
Celem trzyletniego doświadczenia polowego była ocena reakcji pszenicy ozimej, odmiany RGT Kilimanjaro na zróżnicowane nawożenie dolistne. Doświadczenie założono w układzie losowanych bloków na polach Podkarpackiego Ośrodka Doradztwa Rolniczego w Boguchwale. Badanym czynnikiem były zróżnicowane warianty nawożenia dolistnego: (B) - dwukrotny oprysk YaraVita Zboże oraz (C) - dwukrotny oprysk YaraVita Zboże, jednokrotny YaraVita Kombiphos i jednokrotny YaraVita Thiotrac, które porównano do kontroli (A). Wykazano, że zmienne warunki pogodowe w latach badań wpłynęły modyfikująco na uzyskane plony. W $2017 \mathrm{r}$. zebrano ponad $9 \mathrm{t} \cdot \mathrm{ha}^{-1}$ ziarna, natomiast w latach 2018 i 2019 odpowiednio o 2,0 i $0,92 \mathrm{t} \cdot \mathrm{ha}^{-1}$ mniej. Po zastosowaniu nawożenia dolistnego $\mathrm{w}$ wariancie C i B uzyskano istotnie wyższe plony w porównaniu do kontroli, odpowiednio o $0,72 \mathrm{t} \cdot \mathrm{ha}^{-}$ ${ }^{1}$ i $0,44 \mathrm{t} \cdot \mathrm{ha}^{-1}$. Czterokrotne nawożenie dolistne (wariant C) wpłynęło na istotny wzrost MTZ oraz indeksów zieloności liści (SPAD) i powierzchni liści (LAI) w porównaniu do kontroli. W przypadku przewodności szparkowej liści (Gs) dowiedziono, że zastosowane nawożenie w wariancie C skutkowało zmniejszeniem odczytów w odniesieniu do kontroli. Użyte nawozy dolistne w wariancie $\mathrm{C}$ wpłynęły także na istotny wzrost zawartości w ziarnie białka ogólnego a spadek włókna w odniesieniu do kontroli. W przypadku wariantu B uzyskane różnice były nieistotne. W uprawie pszenicy ozimej należy zatem zalecać intensywniejszy wariant nawożenia dolistnego.
\end{abstract}

\begin{abstract}
Słowa kluczowe: Triticum aestivum L., makroelementy, mikroelementy, komponenty plonu, plon, skład chemiczny ziarna, nawożenie

The aim of the three-year field experiment was to evaluate the reaction of winter wheat, RGT Kilimanjaro cultivar to different foliar fertilization._The experiment was set up in a randomized blocks in the fields of the Podkarpackie Agricultural Advisory Center in Boguchwała. The tested factor consisted of various variants of foliar fertilization: B - two-time spraying of YaraVita Grain and C - two-time spraying of YaraVita Grain, one-time YaraVita Kombiphos and one-time YaraVita Thiotrac, which were compared to the control (A). It was shown that the variable weather conditions in the years of the research had a modifying effect on the yields obtained. In 2017, more than $9 \mathrm{t} \cdot \mathrm{ha}^{-1} \mathrm{grain}$ was harvested, while in 2018 and 2019, by 2.0 and $0.92 \mathrm{t} \cdot \mathrm{ha}^{-1}$ less, respectively. After applying foliar fertilization in variants $\mathrm{C}$ and $\mathrm{B}$, the yields were significantly higher compared to the control, by $0.72 \mathrm{t} \cdot \mathrm{ha}^{-1}$ and $0.44 \mathrm{t} \cdot \mathrm{ha}^{-1}$, respectively. Fourfold foliar fertilization (variant C) significantly increased WTG and indices of Soil Plant Analysis System (SPAD) and leaf area index (LAI) compared to the control. In the case of the stomatal conductivity of leaves (Gs), it was proved that the applied fertilization in variant $\mathrm{C}$ resulted in a decrease in readings in relation to the control. The foliar fertilizers used in variant $\mathrm{C}$ significantly increased the content of total protein in the grain and the decrease in fiber compared to the control. In the case of variant B, the obtained differences were insignificant. Therefore, in the cultivation of winter wheat, a more intensive variant of foliar fertilization should be recommended.
\end{abstract}

Key words: Triticum aestivum L., macroelements, microelements, yield components, yield, chemical composition, fertilizer

\section{Wstęp}

Pszenica zwyczajna ozima jest najważniejszym zbożem w Polsce. Duży areał uprawy pszenicy wynika z wysokiego potencjału plonowania i możliwości wykorzystania ziarna zarówno na cele konsumpcyjne jak i paszowe. Gatunek ten wymaga starannej agrotechniki, w tym optymalnego nawożenia. Jańczak - Pieniążek i in. (2020) podają, że uprawa pszenicy ozimej w technologii wysokointensywnej wpłynęła na wzrost plonu oraz wyższą zawartość białka ogólnego i glutenu w ziarnie w porównaniu do technologii ekstensywnej. Černý i in. (2010) udowodnili, że nawożenie mineralne pszenicy przyniosło najlepsze rezultaty na glebie o najniższej naturalnej żyzności. Fageria i in. (2009) konkludują, że niezbędne składniki odżywcze dla roślin uprawnych są stosowane głównie do gleby aby zostały pobrane przez system korzeniowy. Dotyczy to zwłaszcza makroelementów. Jednak 
w pewnych okolicznościach, np. korygująca dawka azotu, korzystne jest również wykonanie nawożenia dolistnego (pozakorzeniowego). Smytkiewicz i Podleśny (2020) podają, że coraz częściej nawożenie dolistne poprzedzone jest wykonaniem oceny stan odżywienia roślin. Służą temu różne metody destrukcyjne i niedestrukcyjne, np. pomiar indeksu zieloności liścia - SPAD. Wach (2015) wykazał, że wykonanie takiego pomiaru w trakcie wegetacji pszenicy pozwala wykryć niedobory składników mineralnych (głównie azotu) i podjąć decyzję o nawożeniu uzupełniającym. Jankowski i in. (2016) podkreślają, że w praktyce rolniczej coraz częściej stosuje się nawozy dolistne, aby zmaksymalizować potencjał plonowania pszenicy. Często jest to podstawowa metoda dostarczania roślinom niezbędnych mikroelementów. Chwil (2014) zwraca jednak uwagę, że większy wpływ na plon, komponenty plonu oraz zawartość makroskładników w ziarnie i słomie wywiera nawożenie doglebowe w porównaniu do dolistnego. Sztuder (2007) najwyższą efektywność nawożenia pszenicy $(12,57 \mathrm{~kg}$ ziarna na $1 \mathrm{~kg}$ NPK) uzyskała na obiekcie, na którym użyła przedsiewnie nawozu zawiesinowego NPK, a pogłównie roztworu mocznika. W badaniach Blecharczyka i in. (2019) najkorzystniej na plonowania pszenicy ozimej wpłynęło łączne nawożenie obornikiem z NPK. Lemańczyk i Piekarczyk (2013) podają jednak, że zwiększenie dawki nawożenia mineralnego z 147 do $221 \mathrm{~kg}$ NPK na ha spowodowało wzmożone występowanie ocenianych chorób. Podolska i Wyzińska (2011) wykazały zróżnicowaną reakcję pszenicy ozimej na nawożenie azotem. W rezultacie badań wydzieliły dwie grupy odmian produktywnie wykorzystującą dawkę 2,4 g N na wazon i wykorzystującej dawkę 3,6 g N na wazon. Zróżnicowaną reakcję poszczególnych odmian pszenicy ozimej na nawożenie azotem potwierdzili również Chrzanowska-Drożdż i in. (2004). Potarzycki i in. (2015) niezależnie od formy chemicznej siarki (S) w nawozach, uzyskali korzystny wpływ tego składnika (25 $\left.\mathrm{kg} \cdot \mathrm{ha}^{-1}\right)$ na plon ziarna pszenicy ozimej. Przy czym największy efekt plonotwórczy wykazały siarczan wapnia pochodzący z superfosfatu prostego i siarczanu amonu stosowanych wiosną. Kocoń (2009) wykazała, że efektywność plonotwórcza dokarmiania dolistnego zależała od gatunku rośliny oraz zestawu i składu użytych nawozów. Największy przyrost plonu badanych gatunków roślin uzyskała po zastosowaniu najszerszego asortymentu nawozów dolistnych, zarówno w okresie jesiennym (jednorazowo), jak i wiosennym (3-krotnie). Z kolei Froese i in. (2020) po dolistnym zastosowaniu fosforu nie uzyskali wzrostu plonu oraz poprawy jakość ziarna pszenicy. Makarewicz i in. (2012) największą zawartość białka ogólnego w suchej masie ziarna pszenicy ozimej odnotowali na obiektach nawożonych dolistnie dawką 10\% roztworu mocznika. Korzeniowska i Stanisławska-Glubiak (2011) oznaczyły średnią zawartość miedzi w ziarnie na poziomie $2,4-2,6 \mathrm{mg} \mathrm{kg}^{-1}$. Jednokrotny oprysk miedzią w dawce $305 \mathrm{~g} \mathrm{ha}^{-1}$ nie spowodował istotnego wzrostu zawartości tego pierwiastka w ziarnie badanych odmian pszenicy ozimej, co najprawdopodobniej wynikało z efektu tzw. rozcieńczenia. Kantek i Korzeniowska (2013) wykazały, że pszenica wykazuje duże zapotrzebowanie na mangan i miedź. W uzasadnionym przypadku zamiast nawozu wieloskładnikowego proponują zastosować jednoskładnikowy. Ruszkowska i Wojcieska - Wyskupajtys (1996) podają, że zarówno niedobór jak i nadmiar mikroelementów jest szkodliwy dla roślin uprawnych. Stąd zwracają uwagę na konieczność prawidłowego nawożenia mikroelementami, tj. żelazo, cynk czy miedź. Fageria i in. (2009) stwierdzają, że jeżeli nawożenie dolistne zostanie zmieszane $\mathrm{z}$ herbicydami powschodowymi, insektycydami lub fungicydami, oczekiwany wzrost plonów może być zwiększony, a koszt aplikacji nawozów dolistnych zmniejszony.

Cele pracy było określenie reakcji pszenicy zwyczajnej ozimej, odmiany RGT Kilimanjaro na zróżnicowane nawożenie dolistne. W hipotezie badawczej założono, że zastosowane warianty zmodyfikują badane cechy biometryczne oraz wielkość i jakość plonu ziarna.

\section{Material i Metody}

Ścisłe doświadczenie polowe założono w Podkarpackim Ośrodku Doradztwa Rolniczego w Boguchwale (215' $\left.49^{\circ} 59^{\prime} N\right)$. Przeprowadzone zostało w sezonach 2016/2017, 2017-2018 i 2018/2019. Doświadczenie przeprowadzono jako jednoczynnikowe w układzie losowanych bloków w czterech powtórzeniach. W badaniach uwzględniono odmianę RGT Kilimanjaro (RAGT Semences). Jest to jedna z plenniejszych odmian pszenicy ozimej, należąca do grupy jakościowej A. Od 2017 r. jest rekomendowana do uprawy w województwie podkarpackim. Schemat nawożenia doglebowego (pod całe doświadczenie) i dolistnego (badany 
czynnik) przedstawiono w tabeli 1.

Skład nawozów stałych, które użyto pod całe doświadczenie przedstawiono w tabeli 2. Nawozy YaraMila 14-14-21 Viking i YaraBela Sulfan to nawozy wieloskładnikowe. Nawóz YaraBela EXTRAN to nawóz azotowy.

Skład nawozów dolistnych przedstawiono w tabeli 3. Nawozy YaraVita Zboże i YaraVita
Kombiphos zawieraja zarówno makro- jak i mikroelementy. Nawóz YaraVita Thiotrac zawiera tylko azot i siarkę.

Łączna dawka składników pokarmowych zastosowanych w nawożeniu pszenicy ozimej została przedstawiona $\mathrm{w}$ tabeli 4 . W przypadku wapnia i boru różnic pomiędzy zastosowanymi wariantami nawożenia nie było.

Tabela 1

Schemat zróżnicowanego nawożenia pszenicy ozimej

Scheme of diversified fertilization of winter wheat

\begin{tabular}{|c|c|c|c|c|}
\hline \multirow{2}{*}{$\begin{array}{l}\text { Termin nawożenia } \\
\text { Date of fertilization }\end{array}$} & \multirow{2}{*}{$\begin{array}{l}\text { Forma nawozy } \\
\text { Form of fertilizers }\end{array}$} & \multicolumn{3}{|c|}{ Wariant/Variant } \\
\hline & & $\begin{array}{l}\text { A (kontrola/ } \\
\text { kontrol) }\end{array}$ & $\mathrm{B}$ & $\mathrm{C}$ \\
\hline $\begin{array}{l}\text { Jesień/Autumn } \\
\text { (BBCH 12) }\end{array}$ & $\begin{array}{l}\text { dolistna } \\
\text { foliar }\end{array}$ & - & $\begin{array}{l}\text { YaraVita } \\
\text { Zboże } \\
(0,5 \text { l/ha })\end{array}$ & $\begin{array}{l}\text { YaraVita Zboże } \\
\quad(0,51 / \text { ha })\end{array}$ \\
\hline $\begin{array}{l}\text { Przed ruszeniem wegetacji na wiosnę/Before the start } \\
\text { of vegetation in the spring (BBCH } 22-23)\end{array}$ & $\begin{array}{l}\text { doglebowa } \\
\text { soil }\end{array}$ & \multicolumn{3}{|c|}{ YaraMila 14-14-21 Viking (300 kg/ha) } \\
\hline $\begin{array}{l}\text { Krzewienie/Tillering } \\
\quad(\mathrm{BBCH} 27)\end{array}$ & $\begin{array}{l}\text { dolistna } \\
\text { foliar }\end{array}$ & - & - & $\begin{array}{c}\text { YaraVita Kom- } \\
\text { biphos } \\
(41 / \text { ha })\end{array}$ \\
\hline $\begin{array}{l}\text { Strzelanie w źdźbło/Shooting } \\
\text { (BBCH 31) }\end{array}$ & $\begin{array}{l}\text { doglebowa } \\
\text { soil }\end{array}$ & \multicolumn{3}{|c|}{$\begin{array}{l}\text { YaraBela EXTRAN } \\
\quad(200 \mathrm{~kg} / \mathrm{ha})\end{array}$} \\
\hline $\begin{array}{l}\text { Liść flagowy/Flag leaf } \\
\text { (BBCH 41) }\end{array}$ & $\begin{array}{l}\text { dolistna } \\
\text { foliar }\end{array}$ & - & $\begin{array}{l}\text { YaraVita } \\
\text { Zboże } \\
(11 / \text { ha })\end{array}$ & $\begin{array}{l}\text { YaraVita Zboże } \\
\qquad(11 / \text { ha })\end{array}$ \\
\hline $\begin{array}{l}\text { Początek kłoszenia/Heading begins } \\
\text { (BBCH 51) }\end{array}$ & $\begin{array}{c}\text { doglebowa } \\
\text { soil }\end{array}$ & \multicolumn{3}{|c|}{ YaraBela Sulfan $(200 \mathrm{~kg} / \mathrm{ha})$} \\
\hline Dojrzałość mleczna ziarna/Milk stage (BBCH 73) & $\begin{array}{l}\text { dolistna } \\
\text { foliar }\end{array}$ & - & - & $\begin{array}{c}\text { YaraVita Thiotrac } \\
(5 \mathrm{l} / \mathrm{ha})\end{array}$ \\
\hline
\end{tabular}

Tabela 2

Table 2

Skład chemiczny nawozów doglebowych w\%

Chemical composition of soil fertilizers in $\%$

\begin{tabular}{ccccccc}
\hline Nawóz stały & N & P & K & Mg & Ca & S \\
\hline YaraMila 14-14-21 Viking & 14 & 14 & 21 & 0,7 & & \\
YaraBela EXTRAN & 33,5 & & & & & \\
YaraBela Sulfan & 24 & & 1,5 & 10,5 & 16,2 \\
\hline
\end{tabular}

Tabela 3

Table 3

Skład chemiczny nawozów dolistnych w g/l

Chemical composition of foliar fertilizers in $\mathrm{g} / \mathrm{l}$

\begin{tabular}{ccccccccc}
\hline Nawóz dolistny & $\mathrm{N}$ & $\mathrm{P}$ & $\mathrm{K}$ & $\mathrm{Mg}$ & $\mathrm{S}$ & $\mathrm{Cu}$ & $\mathrm{Mn}$ & $\mathrm{Zn}$ \\
\hline YaraVita Zboże & 64 & & & 250 & & 50 & 150 & 80 \\
YaraVita Kombiphos & & 440 & 75 & 67 & & & 10 & 5 \\
YaraVita Thiotrac & 200 & & & & 750 & & & \\
\hline
\end{tabular}


Diagram nawożenia w $\mathrm{kg} \cdot \mathrm{ha}^{-1}$

Fertilization diagram in $\mathbf{k g} \cdot \mathrm{ha}^{-1}$

\begin{tabular}{cccc}
\hline \multirow{2}{*}{ Składnik/Nutrients } & \multicolumn{3}{c}{ Wariant/Variant } \\
\cline { 2 - 4 } N & A (kontrola/control) & B & 158,1 \\
P & 157 & 157,1 & 43,76 \\
K & 42 & 42 & 63,3 \\
Ca & 63 & 63 & 21 \\
Mg & 21 & 21 & 5,74 \\
S & 5,1 & 5,48 & 36,15 \\
B & 32,4 & 32,4 & 0,06 \\
Cu & 0,06 & 0,06 & 0,08 \\
Mn & & 0,08 & 0,27 \\
Zn & & 0,23 & 0,14 \\
\hline
\end{tabular}

Doświadczenie założono na glebie kompleksu pszennego bardzo dobrego, klasy bonitacyjnej II. Odczyn gleby był lekko kwaśny. Zawartość przyswajalnego fosforu i potasu oceniono jako wysoką, magnezu średnią a siarki średnią lub niską (tab. 5).
Zawartość mikroelementów oceniono jako średnią za wyjątkiem niskiej boru. Analizę próbek glebowych wykonano w Okręgowej Stacji Chemiczno -Rolniczej w Rzeszowie.

\section{Analiza chemiczna gleby}

\section{Chemical analysis of soil}

\begin{tabular}{ccccc}
\hline Parametr/Parameter & Jednostka/Unit & 2016 & 2017 & 2018 \\
\hline $\mathrm{pH} \mathrm{w} /$ in $\mathrm{KCl}$ & - & 5,9 & 5,7 & 5,6 \\
\hline Próchnica/Humus & $\%$ & 1,53 & 1,31 & 1,27 \\
\hline $\mathrm{P}_{2} \mathrm{O}_{5}$ & & 19,5 & 18,5 & 18,3 \\
$\mathrm{~K}_{2} \mathrm{O}$ & $\mathrm{mg} \cdot 100 \mathrm{~g}^{-1}$ gleby/soil & 23,3 & 24,2 & 22,1 \\
$\mathrm{Mg}$ & & 6,5 & 6,7 & 5,8 \\
$\mathrm{~S}-\mathrm{SO}_{4}$ & & 1,9 & 2,1 & 1,7 \\
$\mathrm{Fe}$ & & 1707 & 2523 & 3186 \\
$\mathrm{Zn}$ & $\mathrm{mg} \cdot 1000 \mathrm{~g}^{-1}$ gleby/soil & 10,3 & 8,8 & 15,6 \\
$\mathrm{Mn}$ & & 357 & 438 & 521 \\
$\mathrm{Cu}$ & & 4,3 & 5,3 & 6,4 \\
$\mathrm{~B}$ & & 1,2 & 0,9 & 0,9 \\
\hline
\end{tabular}

Przedplonem był rzepak ozimy, po zbiorze którego pobrano próbkę glebową $(1 \mathrm{~kg})$ do analiz chemicznych. Uprawa polegała na wykonaniu podorywki, bronowania i orki siewnej. Przed siewem zastosowano agregat uprawowy. Materiał siewny zaprawiono preparatem Gizmo 060 FS $(50 \mathrm{ml} / 100 \mathrm{~kg}$ ziarna). Siew wykonano w terminie: 28.09.2016 r., 29.09.2017 r. i 28.09.2018 r. stosując 350 ziaren $\cdot \mathrm{m}^{-2}$.
Ziarno umieszczono w glebie na głębokości 3-4 cm przy szerokości międzyrzędzi $12,5 \mathrm{~cm}$. Powierzchnia pojedynczego poletka wynosiła $15,0 \mathrm{~m}^{2}$ a pasy izolacyjne $1 \mathrm{~m}$. W trakcie okresu wegetacji prowadzono chemiczną pielęgnację roślin (tab. 6). Zabiegi chemiczne były wykonywane opryskiwaczem ciągnikowym, zaś nawożenie dolistne opryskiwaczem plecakowym. 
Chemical plant protection treatments

\begin{tabular}{ccc}
\hline Preparat/Preparation & Termin/Term & Dawka/Dose \\
\hline Ekspert Met 56 WG & BBCH 11 & 1 l/ha \\
Huzar Activ 387 OD & BBCH 25 & $0,35 \mathrm{~kg} / \mathrm{ha}$ \\
Antywylegacz 725 SL + Modus 250 EC & BBCH 30 & $1,2+0,4$ 1/ha \\
Karate Zeon 050 CS & BBCH 51 & $1 / \mathrm{ha}$ \\
Boogie Xpro 400 EC & BBCH 55 $1 / \mathrm{ha}$ & $11 / \mathrm{ha}$ \\
Fandango 200 EC & BBCH 58 & \\
\hline
\end{tabular}

\section{Obserwacje i Pomiary}

Warunki pogodowe podano według notowań stacji meteorologicznej Podkarpackiego Ośrodka Doradztwa Rolniczego w Boguchwale

Fazy rozwojowe przedstawiono według skali $\mathrm{BBCH}$ (Bundesanstalt, Bundessortenamt und CHemische Industrie). Pomiar przewodności szparkowej liści (Gs) wykonano aparatem Porometr SC-1 (Meter, USA). Indeks zieloności liści (SPAD) zmierzono za pomocą chlorofilomierza SPAD 502P (Konica Minolta, Japonia). Do określenia powierzchni liści (LAI) użyto aparatu AccuPAR LP-80 (Meter, USA). Pomiary Gs, SPAD i LAI zmierzono w fazie BBCH 75.

Obsadę kłosów policzono na powierzchni $1 \mathrm{~m}^{2}$ przed zbiorem. Liczbę ziaren w kłosie i MTZ określono na roślinach pobranych z $0,5 \mathrm{~m}^{2}$. Zbiór przeprowadzono kombajnem poletkowym $\mathrm{w}$ dniach: 4.08. 2017 r., 3.08. 2018 r. i 30.07. 2019 r. Uzyskany plon przeliczono na 1 ha, przy $14 \%$ wilgotności ziarna.

Skład chemiczny ziarna oznaczono metodą bliskiej podczerwieni na aparacie Spektrometr FT-LSD MPA (firma Bruker, Niemcy) w laboratorium Zakładu Produkcji Roślinnej Uniwersytetu Rzeszowskiego.

Istotność różnic pomiędzy wartościami cech stwierdzono na podstawie półprzedziałów ufności Tukeya, przy poziomie istotności $\alpha=0,05$. Obliczenia wykonano programem statystycznym ANALWAR-5.3.FR

\section{Wyniki i Dyskusja}

Warunki pogodowe były zróżnicowane w latach badań (tab. 7). We wrześniu 2018 roku odnotowane niskie opady deszczu. Najchłodniejszym miesiącem był styczeń w latach 2017 i 2019, zaś luty w 2018 r. W kwietniu 2018 r. i 2019 r. opady deszczu były poniżej średniej wieloletniej. Zaznaczyć należy, że kwiecień w 2018 r. był znacząco cieplejszy w porównaniu do danych wieloletnich. Intensywne opady deszczu odnotowano w maju 2019 r. Natomiast w czerwcu każdego roku opady utrzymywały się poniżej średniej wieloletniej. Czerwiec 2019 r. był najcieplejszym miesiącem w okresie wegetacji pszenicy. Zmienny układ warunków pogodowych w poszczególnych sezonach wpłynął na zróżnicowanie uzyskiwanych plonów ziarna.

Sułek i in. (2016) podają, że warunki pogodowe determinowały poziom plonowania i nasilenie chorób grzybowych pszenicy. Tsvey i in. (2021) stwierdzili, że w latach o regularnych opadach w okresie wegetacji (2018-2019) nawozy azotowe miały większy wpływ na plon pszenicy ozimej niż w roku z niedoborem opadów (2017). Z kolei zmiany zawartości białka w ziarnie były mniej zależne od warunków atmosferycznych.

Zastosowane warianty nawożenia nie wywarły istotnego wpływu na liczbę kłosów z $1 \mathrm{~m}^{2}$, ani na liczbę ziaren w kłosie. Wykazano, że dorodniejsze ziarno wydały rośliny po zastosowaniu nawożenia $\mathrm{w}$ wariancie $\mathrm{C} \mathrm{w}$ porównaniu do wariantu A (tab. 8). Uzyskana istotna różnica wyniosła 1,8 g.

Jaskulska i in. (2015) wykazali, że wieloletnie pomijanie choćby jednego podstawowego makroskładnika w nawożeniu mineralnym, mimo stosowania obornika, skutkuje zmniejszeniem udziału ziarna dużego, a wzrostem udziału w plonie ziarna drobniejszego, głównie frakcji 2,2-2,5 $\mathrm{mm}$. Jankowski i in. (2016) najwyższy plon ziarna pszenicy ozimej $\left(10,16\right.$ tha $\left.^{-1}\right)$ uzyskali po zastosowaniu pięciokrotnej aplikacji dolistnej makroelementów i mikroelementów $\mathrm{W}$ porównaniu z poletkami, na których nawozy dolistne użyto dwukrotnie. Uzyskany przyrost plonu wynikał ze wzrostu MTZ (optymalny poziom opadów) lub wzrostu liczby kłosów na $1 \mathrm{~m}^{2}$ (niski poziom opadów). Kocoń (2009) oraz Buczek i in. (2012) potwierdzają, że nawożenie dolistne pszenicy ozimej skutkuje przede wszystkim wzrostem MTZ. 
Warunki pogodowe w latach 2016-2019

Weather conditions in 2016-2019

\begin{tabular}{|c|c|c|c|c|c|c|c|c|}
\hline \multirow{2}{*}{$\begin{array}{l}\text { Miesiąc } \\
\text { Month }\end{array}$} & \multicolumn{4}{|c|}{$\begin{array}{l}\text { Sumy opadów }(\mathrm{mm}) \\
\text { Rainfall totals }(\mathrm{mm})\end{array}$} & \multicolumn{4}{|c|}{$\begin{array}{c}\text { Średnie temperatury powietrza }\left({ }^{\circ} \mathrm{C}\right) \\
\text { Average air temperatures }\end{array}$} \\
\hline & $\begin{array}{l}2016 / \\
2017\end{array}$ & $\begin{array}{l}2017 / \\
2018\end{array}$ & $2018 / 2019$ & $\begin{array}{l}\text { wielolecie } \\
\text { multi-year }\end{array}$ & $\begin{array}{l}2016 / \\
2017\end{array}$ & $\begin{array}{l}2017 / \\
2018\end{array}$ & $2018 / 2019$ & $\begin{array}{l}\text { wielolecie } \\
\text { multi-year }\end{array}$ \\
\hline IX & 40 & 107 & 19 & 63 & 15,4 & 13,8 & 15,1 & 13,6 \\
\hline $\mathrm{X}$ & 119 & 80 & 28 & 47 & 7,5 & 10,0 & 9,8 & 8,8 \\
\hline XI & 36 & 47 & 14 & 38 & 3,5 & 4,3 & 5,0 & 3,6 \\
\hline XII & 50 & 103 & 30 & 37 & $-0,7$ & 2,1 & 0,9 & $-0,5$ \\
\hline I & 4 & 23 & 17 & 31 & $-6,0$ & 0,9 & $-2,8$ & $-2,3$ \\
\hline II & 28 & 25 & 11 & 29 & 0,3 & $-1,5$ & 2,7 & $-1,2$ \\
\hline III & 37 & 53 & 23 & 37 & 6,2 & 0,3 & 5,9 & 2,8 \\
\hline IV & 55 & 18 & 21 & 46 & 8,2 & 13,8 & 9,9 & 8,7 \\
\hline V & 86 & 81 & 112 & 77 & 13,5 & 16,3 & 13,1 & 13,7 \\
\hline VI & 41 & 45 & 31 & 80 & 18,4 & 18,2 & 21,5 & 17,1 \\
\hline VII & 95 & 83 & 50 & 95,2 & 18,7 & 19,3 & 19,1 & 19,0 \\
\hline
\end{tabular}

Komponenty plonu (średnia z lat)

Yield components (mean for year)

\begin{tabular}{cccc}
\hline $\begin{array}{c}\text { Wariant nawożenia } \\
\text { Fertilization variant }\end{array}$ & $\begin{array}{c}\text { Obsada kłosów }\left(\mathrm{szt} \cdot \mathrm{m}^{-2}\right) \\
\text { Number of ears } \\
\left(\mathrm{pcs} \cdot \mathrm{m}^{-2}\right)\end{array}$ & $\begin{array}{c}\text { Liczba ziaren w kłosie } \\
\text { Number of grains per ear }\end{array}$ & $\begin{array}{c}\text { MTZ }(\mathrm{g}) \\
\text { Thousand grain weight } \\
(\mathrm{g})\end{array}$ \\
\hline A (kontrola/control) & 496,1 & 39,3 & 39,3 \\
$\mathrm{~B}$ & 501,3 & 40,1 & 40,3 \\
$\mathrm{C}$ & 498,3 & r.n. & 41,1 \\
NIR $_{0,05}$ LSD $_{0,05}$ & r.n. & 40,1 \\
\hline Średnia ogólna \\
Total mean
\end{tabular}

r.n. - różnica nieistotna/nonsignificant difference

Zastosowane nawożenie w wariancie C, w odniesieniu do kontroli, wpłynęło na zwiększenie wartości pomiarów LAI i SPAD, co świadczy o korzystnym wpływie zastosowanych nawozów na wzrost i stan odżywienia roślin. Istotnie niższe odczyty wymienionych indeksów uzyskano u roślin kontrolnych. W przypadku przewodności szparkowej liści (Gs) wykazano, że nawożenie w wariancie $\mathrm{C}$ skutkowało spadkiem pomiarów w porównaniu do kontroli (tab. 9). Nawozy dolistne wywarły zatem krótkotrwały stres u roślin, który wynikał z bezpośredniego kontaktu z substancjami zawartymi w nawozach.

Kocoń (2016) zwraca uwagę, że przy nawożeniu dolistnym konieczne jest odpowiednie przygotowanie cieczy roboczej aby nie powodować dodatkowego stresu u roślin a nawet ich poparzenia. Zagórda i Walczyk (2007) wykazali przydatność odczytów SPAD w uprawie pszenicy ozimej do oceny stanu odżywienia roślin. W rezultacie takich pomiarów uzyskali zadowalający plon ziarna i mniejsze o blisko 14\% zużycie azotu w odniesieniu do nawożenia tradycyjnego. Rachoń i in. (2018) udowodnili, że odczyty LAI zależały od genotypu pszenicy jarej oraz zastosowanej intensywności produkcji. Wykazali, że w fazie kwitnienia zaznaczył się korzystny wpływ intensywniejszej agrotechniki na uzyskane pomiary LAI. Bobrecka-Jamro i in. (2015) podają, że większa dawka nawożenia mineralnego NPK w porównaniu z niższą wpłynęła na istotny wzrost indeksów SPAD i LAI w uprawie pszenicy jarej. Fageria i in. (2009) konkludują, że nawożenie dolistne wymaga większej powierzchni liści, aby wchłonąć aplikowane makro- i mikroskładniki 
w wystarczajacej ilości. Często konieczne jest wykonanie więcej niż jednej aplikacji dolistnej w zależności od stopnia niedoboru składników pokarmowych w roślinie.

Tabela 9

Table 9

Pomiary wskaźników (średnia z lat)

Measurements of indicators (average over the years)

\begin{tabular}{cccc}
\hline $\begin{array}{c}\text { Wariant nawożenia } \\
\text { Fertilization variant }\end{array}$ & SPAD & LAI & Gs \\
\hline A (kontrola/control) & 53,3 & 3,55 & 613,8 \\
$\mathrm{~B}$ & 55,6 & 3,72 & 593,4 \\
$\mathrm{C}$ & 58,2 & 4,33 & 580,6 \\
$\mathrm{NIR}_{0,05} \mathrm{LSD}_{0,05}$ & 4,76 & 0,69 & 31,6 \\
\hline Średnia ogólna & 55,7 & 3,87 & 595,9 \\
Total mean & & \\
\hline
\end{tabular}

r.n. - różnica nieistotna/nonsignificant difference

W latach badań plon ziarna pszenicy ozimej wyniósł średnio $8,05 \mathrm{t} \cdot \mathrm{ha}^{-1}$. Istotny wzrost poziomu plonowania w stosunku do obiektu kontrolnego uzyskano po zastosowaniu nawożenia $\mathrm{w}$ wariancie $\mathrm{C}$ i B. Wzrost plonu ziarna w odniesieniu do kontroli po zastosowaniu wariantu $C$ wyniósł $0,72 \mathrm{t} \cdot \mathrm{ha}^{-1}$. Natomiast po zastosowaniu wariantu B 0,44 th $^{-1}{ }^{-1}$. Plony pszenicy były zróżnicowane w latach badań. W 2017 r. uzyskano 9,02 tha $a^{-1}$ ziarna, natomiast w latach 2018 i 2019 odpowiednio o 2,0 i 0,92 tha 1 mniej. W latach badań plonowanie pszenicy ozimej było zmodyfikowane poprzez zmienne nawożenie. Należy zaznaczyć, że w 2018 r. nawożenie w wariancie $\mathrm{C}$ skutkowało najwyższym przyrostem plonu w porównaniu do kontroli, o 0,96 th ha- ${ }^{-1}$. Potwierdzono także istotną różnicą plonu pomiędzy wariantem nawożenia $\mathrm{B}$ w odniesieniu do kontroli (tab. 10). Należy zatem wnioskować, że rośliny pszenicy ozimej korzystnie reagują na zawarte w nawozach dolistnych składniki pokarmowe. Wykonanie analiz chemicznych liści pozwoliłoby uszczegółowić uzyskane wyniki, na co potrzeba jednak odpowiednich środków finansowych.

Podolska i Wyzińska (2011) wykazały korzystny wpływ azotu na plon ziarna pszenicy ozimej, co było związane ze wzrostem liczby kłosów na wazon, liczby ziaren $\mathrm{z}$ rośliny oraz zależnie od odmiany MTZ. Sztuder (2007) udowodniła, lepszą przyswajalności składników z nawozów płynnych (NPK) w porównaniu z nawozami stałymi. Buczek i in. (2012) potwierdzają, że nawozy dolistne istotnie zwiększały plon ziarna pszenicy ozimej w zakresie od 0,37 do 0,67 tha ${ }^{-1}$. Największy wzrost plonu ziarna (średnio o 12,2\%) uzyskali po aplikacji nawozu Plonvit $\mathrm{Z}$ w stosunku do kontroli.

Tabela 10

Table 10

Plon ziarna w $t \cdot h^{-1}$

Grain yield in $\mathbf{t} \cdot \mathrm{ha}^{-1}$

\begin{tabular}{|c|c|c|c|c|}
\hline $\begin{array}{l}\text { Wariant nawożenia } \\
\text { Fertilization variant }\end{array}$ & 2017 & 2018 & 2019 & $\begin{array}{c}\text { Średnia } \mathrm{z} \text { lat } \\
\text { Mean for years }\end{array}$ \\
\hline A (kontrola/control) & 8,64 & 6,56 & 7,78 & 7,66 \\
\hline B & 9,10 & 6,99 & 8,21 & 8,10 \\
\hline $\mathrm{C}$ & 9,32 & 7,52 & 8,30 & 8,38 \\
\hline $\mathrm{NIR}_{0,05 /} \mathrm{LSD}_{0,05}$ & 0,59 & 0,38 & 0,48 & 0,41 \\
\hline $\begin{array}{l}\text { Średnia ogólna } \\
\text { Total mean }\end{array}$ & 9,02 & 7,02 & 8,10 & 8,05 \\
\hline
\end{tabular}

Zawartość białka ogólnego wyniosła średnio $13,9 \%$ s.m. ziarna. Zastosowane nawożenie $\mathrm{w}$ wariancie $\mathrm{C}$ istotnie zwiększyło koncentracjęomawianegoskładnika wziarnie odniesieniu do kontroli. W przypadku włókna uzyskano zależność odwrotną. Więcej omawianego składnika oznaczono w ziarnie z kontroli (A) w porównaniu do wariantu C. Zawartość tłuszczu surowego i popiołu nie była istotnie zmodyfikowana (tab. 11). Chrzanowska-Drożdż i in. (2004) wykazały, 
że uzyskanie dobrych wskaźników jakościowych ziarna pszenicy wymagało zastosowania $120 \mathrm{~kg}$ / ha azotu i dodatkowo dolistnego dokarmiania mocznikiem. Knapowski i in. (2010) po dolistnym zastosowaniu $30 \mathrm{~kg} \cdot \mathrm{ha}^{-1}$ azotu $\mathrm{w}$ fazie strzelania w źdźbło, uzyskali istotnie najwyższą zawartość białka w ziarnie pszenicy ozimej odmiany Astella. Buczek i in. (2012) podają, że nawożenie dolistne korzystnie wpływało na cechy jakościowe ziarna, poprzez zwiększenie zawartości białka oraz dodatkowo dorodności nasion. Również Jaskulska (2010) wykazała, że ziarno pszenicy ozimej pod wpływem nawożenia makro- i mikroelementami zawierało więcej białka a często i glutenu. W badaniach Jankowskiego i in. (2016) intensywne nawożenie dolistne istotnie obniżyło zawartość białka ogólnego (1,1 $\mathrm{g} \mathrm{kg}^{-1}$ s.m.) oraz pogorszyło jakość białka w porównaniu do kontroli.

Tabela 11

Table 11

Sklad chemiczny ziarna w\% s.m. (średnia z lat)

Chemical composition of grain in\% DM (average over the years)

\begin{tabular}{|c|c|c|c|c|}
\hline $\begin{array}{l}\text { Wariant nawożenia } \\
\text { Fertilization variant }\end{array}$ & $\begin{array}{l}\text { Białko ogólne } \\
\text { Total protein }\end{array}$ & $\begin{array}{c}\text { Tłuszcz surowy } \\
\text { Crude fat }\end{array}$ & $\begin{array}{l}\text { Włókno } \\
\text { Fiber }\end{array}$ & $\begin{array}{l}\text { Popiół } \\
\text { Ash }\end{array}$ \\
\hline A (kontrola/control) & 13,5 & 1,53 & 2,88 & 1,49 \\
\hline B & 13,9 & 1,51 & 2,71 & 1,54 \\
\hline $\mathrm{C}$ & 14,4 & 1,48 & 2,53 & 1,58 \\
\hline $\mathrm{NIR}_{0,05 /} \mathrm{LSD}_{0,05}$ & 0,82 & r.n. & 0,31 & r.n. \\
\hline $\begin{array}{l}\text { Średnia ogólna } \\
\text { Total mean }\end{array}$ & 13,9 & 1,51 & 2,71 & 1,54 \\
\hline
\end{tabular}

r.n. - różnica nieistotna/nonsignificant difference

\section{Wnioski}

1. Plonowanie pszenicy ozimej było zmienne w latach badań, na co wpłynął układ warunków pogodowych w poszczególnych sezonach. W 2017 r. uzyskano 9,02 tha ${ }^{-1}$ ziarna, natomiast w latach 2018 i 2019 odpowiednio o 2,0 i $0,92 \mathrm{t} \cdot \mathrm{ha}^{-1}$ mniej.

2. Najwyższy plon ziarna $\left(8,38 \mathrm{t} \cdot \mathrm{ha}^{-1}\right)$ uzyskano po zastosowaniu intensywnego nawożenia dolistnego (wariant $\mathrm{C}$ ) a istotnie niższy na kontroli. Po zastosowaniu wariantu B w odniesieniu do wariantu $\mathrm{C}$ pszenica plonowała na tym samym poziomie.

3. Intensywne nawożenie dolistne (wariant $\mathrm{C}$ ) wpłynęło na istotny wzrost MTZ oraz indeksów SPAD i LAI w odniesieniu do kontroli. W przypadku przewodności szparkowej liści (Gs) wykazano zależność odwrotną.

4. Zastosowane nawożenie $\mathrm{w}$ wariancie $\mathrm{C}$ istotnie zwiększyło w ziarnie zawartość białka ogólnego, zaś obniżyło włókna w porównaniu do kontroli.

\section{Literatura}

Bobrecka-Jamro, D., Jarecka, A., Jarecki, W. (2015). Response of some spring wheat cultivars to diverse mineral NPK fertilization. Acta Sci. Pol. Agricultura, 14 (2): 3-13.

Buczek, J., Tobiasz-Salach, R., Bobrecka-Jamro, D. (2012).
Wpływ nawożenia dolistnego i zmniejszonych dawek herbicydu na plon i cechy jakościowe ziarna pszenicy ozimej. Fragm. Agron., 29 (1): 7-15.

Černý, J., Balík, J., Kulhánek, M., Čásová, K., Nedvěd, V. (2010). Mineral and organic fertilization efficiency in long-term stationary experiments. Plant Soil Environ., 56: 28-36. https://doi.org/10.17221/200/2009-PSE

Chrzanowska-Drożdż, B., Gil, Z., Liszewski, M., Malarz, W. (2004). Wysokość i jakość plonu ziarna pszenicy ozimej w zależności od dawki i sposobu nawożenia azotem. Biuletyn IHAR, 233: 29-38.

Chwil, S. (2000). Plonowanie pszenicy ozimej pod wpływem dolistnego dokarmiania wieloskładnikowym nawozem Wuxal Top N w warunkach zróżnicowanego nawożenia azotem. Rocz. Gleb., 51 (3/4): 129-134.

Chwil, S. (2014). Effects of foliar feeding under different soil fertilization conditions on the yield structure and quality of winter wheat (Triticum aestivum L.). Acta Agrobot., 67 (4): 135-144.

Dick, C.D., Thompson, N.M., Epplin, F.M., Arnall, D.B. (2016). Managing late-season foliar nitrogen fertilization to increase grain protein for winter wheat. Agron. J., 108 (6): 2329-2338. DOI: 10.2134/agronj2016.02.0106

Fageria, N.K., Barbosa, Filho M.P., Moreira, A., Guimarães, C.M. (2009). Foliar Fertilization of Crop Plants. J. Plant Nutr., 32 (6): 1044-1064, DOI: 10.1080/01904160902872826

Froese, S., Wiens, J.T., Warkentin, T., Schoenau, J.J. (2020). Response of canola, wheat and pea to foliar phosphorus 
fertilization at a phosphorus deficient site in eastern Saskatchewan. Can. J. Plant Sci., 100 (6): 642-652 DOI: 10.1139/cjps-2019-0276

Jankowski, K.J., Hulanicki, P.S., Sokólski, M., Hulanicki, P., Dubis, B. (2016). Yield and quality of winter wheat (Triticum aestivum L.) in response to different systems of foliar fertilization. J. Elem., 21 (3): 715-728. DOI: 10.5601/jelem.2015.20.4.1036

Jańczak-Pieniążek, M., Buczek, J., Tobiasz-Salach, R., Bobrecka-Jamro, J. (2020). Wpływ intensywności uprawy na produkcyjność mieszańcowych i populacyjnych odmian pszenicy ozimej. Biuletyn IHAR, 288: 59-66. DOI: $10.37317 /$ biul-2020-0007

Jaskulska, I. (2010). Wpływ dolistnego stosowania makroi mikroelementów na wielkość i jakość plonów pszenicy ozimej i buraka cukrowego. Zesz. Probl. Post. Nauk Rol. 556: $119-126$

Jaskulska, I., Boczkowski, T., Janiak, A., Jaskulski, D. (2015). Wpływ wieloletniego zróżnicowanego nawożenia na strukturę plonu i zanieczyszczenie ziarna pszenicy ozimej. Fragm. Agron., 32 (2): 20-28.

Knapowski, T., Ralcewicz, M., Spychaj-Fabisiak, E., Ložek, O. (2010). Ocena jakości ziarna pszenicy ozimej uprawianej w warunkach zróżnicowanego nawożenia azotem. Fragm. Agron., 27 (1): 73-80.

Kocoń, A. (2009). Efektywność dolistnego dokarmiania pszenicy i rzepaku ozimego wybranymi nawozami w warunkach optymalnego nawożenia i wilgotności gleby. Ann. UMCS, Sec. E, 64 (2): 23-28. DOI: 10.2478/ v10081-009-0014-0

Kocoń, A. (2016). Aktualne trendy i innowacje w dolistnym dokarmianiu roślin uprawnych*. Studia i Raporty IUNG-PIB Puławy, (48)2: 49-63. DOI: 10.26114/sir. iung.2016.48.04

Kantek, K., Korzeniowska, J. (2013). Potrzeby nawożenia zbóż mikroelementami. Studia i Raporty IUNG-PIB Puławy, 34 (8): 145-157. DOI: 10.26114/sir.iung.2013.34.11

Korzeniowska, J., Stanisławska-Glubiak, E. (2011). The effect of foliar application of copper on content of this element in winter wheat grain. Pol. J. Agron., 4: 3-6.

Lemańczyk, G., Piekarczyk, M. (2013). Effect of fertilization, chemical crop protection and sowing density on health status of winter wheat grown in short-time monoculture on light soil. Prog. Plant Prot./Post. Ochr. Roślin, 53 (3): 487-493

Makarewicz, A., Gąsiorowska, B., Cybulska, A. 2012. Wpływ dolistnego nawożenia azotem na wybrane parametry jakościowe ziarna pszenicy ozimej. Frag. Agron. 29 (1): 105-113.

Podolska, G., Wyzińska, M. (2011). Reakcja odmian pszenicy ozimej na nawożenie azotem w doświadczeniach wazonowych. Pol. J. Agron., 5: 43-48.

Potarzycki, J., Przygocka-Cyna, K., Wendel, J., Biniek, Ł., Ridiger, B. (2015). Wpływ nawożenia siarką na plonowanie pszenicy ozimej. Fragm. Agron., 32 (4): 63-72.

Rachoń, L., Szumiło, G., Michałek, W., Bobryk-Mamczarz, A. (2018). Zmienność wskaźnika powierzchni liści (LAI) i promieniowania fotosyntetycznie aktywnego (PAR) w zależności od genotypu pszenicy i intensyfikacji technologii uprawy. Agronomy Sci., 73 (1): 63-71. https://doi. org/10.24326/asx.2018.1.6

Ruszkowska, M., Wojcieska - Wyskupajtys, U. (1996). Mikroelementy - fizjologiczne i ekologiczne aspekty ich niedoborów i nadmiarów. Zesz. Probl. Post. Nauk Rol., 434: 1-11.

Smytkiewicz, K., Podleśny, J. 2020. Metody oceny stanu odżywienia roślin azotem. Studia i Raporty IUNG-PIB. Z. 61 (15): 89-99.

Sułek, A., Podolska, G., Jaśkiewicz, B. (2016). Plonowanie i zdrowotność dwóch podgatunków pszenicy w zależności od udziału zbóż w strukturze zasiewów w warunkach integrowanej produkcji. Pol. J Agron., 27: 118-125.

Sztuder, H. (2007). Produkcyjna i ekologiczna ocena różnych sposobów aplikacji nawozów w uprawie pszenicy ozimej. Inż. Rol., 3 (91): 167-172.

Tsvey, Y., Ivanina, R., Ivanina, V., Senchuk, S. (2021). Yield and quality of winter wheat (Triticum aestivum L.) grain in relation to nitrogen fertilization. Rev. Fac. Nac. Agron. Medellín, 74 (1): 9413-9422. DOI: 10.15446/rfnam. v74n1.88835

Wach, D. (2015). Metody oceny stanu odżywiania roślin. Studia i Raporty IUNG PIB Puławy, 42 (16): 53-68. DOI: 10.26114/sir.iung.2015.42.2

Zagórda, M., Walczyk, M. (2007). Precyzyjne nawożenie azotem pszenicy ozimej na podstawie pomiarów SPAD. Inż. Rol., 7 (95): 249-256. 